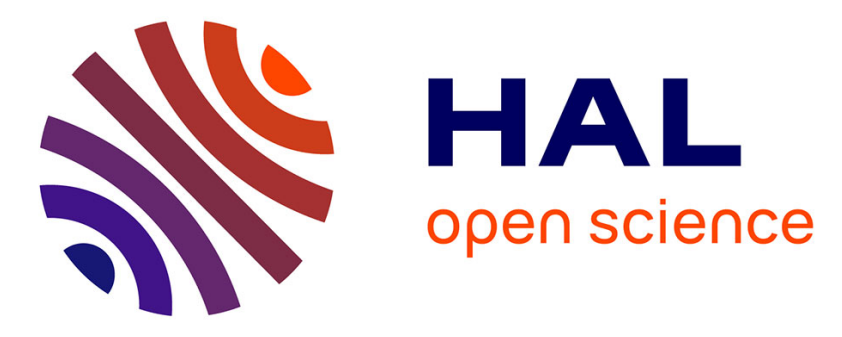

\title{
Sinaspidoneura magnifica nov. gen., nov. sp., first Chinese Caloneurodea (Insecta
}

Diying Huang, Yanzhe Fu, Xinneng Lian, André Nel

\section{To cite this version:}

Diying Huang, Yanzhe Fu, Xinneng Lian, André Nel. Sinaspidoneura magnifica nov. gen., nov. sp., first Chinese Caloneurodea (Insecta. Geobios, 2020, 63, pp.33-37. 10.1016/j.geobios.2020.10.003 . hal-03146794

\section{HAL Id: hal-03146794 https://hal.sorbonne-universite.fr/hal-03146794}

Submitted on 19 Feb 2021

HAL is a multi-disciplinary open access archive for the deposit and dissemination of scientific research documents, whether they are published or not. The documents may come from teaching and research institutions in France or abroad, or from public or private research centers.
L'archive ouverte pluridisciplinaire HAL, est destinée au dépôt et à la diffusion de documents scientifiques de niveau recherche, publiés ou non, émanant des établissements d'enseignement et de recherche français ou étrangers, des laboratoires publics ou privés. 
Sinaspidoneura magnifica nov. gen., nov. sp., first Chinese Caloneurodea (Insecta: Archaeorthoptera)

Huang, Diying ${ }^{\mathrm{a}}, \mathrm{Fu}$, Yanzhe $^{\mathrm{a}}$, Lian Xinneng ${ }^{\mathrm{a}}$, Nel, Andréb

xnlian@nigpas.ac.cn

${ }^{a}$ State Key Laboratory of Palaeobiology and Stratigraphy, Nanjing. Institute of Geology and Palaeontology, Center for Excellence in Life and Paleoenvironment, Chinese Academy of Sciences, Nanjing 210008, PR China; E-mail: dyhuang@nigpas.ac.cn

${ }^{b}$ Institut de Systématique, Evolution, Biodiversité (ISYEB), Muséum national d'Histoire naturelle, CNRS, Sorbonne Université, EPHE, Université des Antilles, CP 50, 57 rue Cuvier, 75005 Paris, France.E-mail: anel@mnhn.fr

\begin{abstract}
We describe the first Chinese Caloneurodea, Sinaspidoneura magnifica nov. gen., nov. sp. from the middle Permian Yinping Formation, in the small family Aspidoneuridae, previously known from two genera and species, one from the latest Carboniferous of France and another from the late early Permian of North America. This discovery shows that this order was more widespread during the Middle Permian than previously supposed, under a great variety of palaeoclimates. This clade is still unknown in the Late Permian, and possibly became extinct because of the crisis of biodiversity that happened at the end of the Middle Permian.
\end{abstract}

Keywords: Aspidoneuridae; paleobiogeography; Laurussia; Southern China; nov. gen., nov. sp.; Middle Permian extinction.

\title{
1. Introduction
}


The small extinct order Caloneurodea Martynov, 1938 is currently only known between the late Carboniferous and the end of the middle Permian, in Western Europe, North America, and Russian Federation. With 22 described genera, it is one of the smallest order of Paleozoic insect orders. Its position was uncertain till Béthoux et al. (2004) discovered that their pattern of wing venation was that of the superorder Archaeorthoptera Béthoux and Nel, 2002, the total group of the recent Orthoptera Olivier, 1789 and some other extinct clades such as the Titanoptera Sharov, 1968. The Caloneurodea are well-characterized by a series of characters of the forewing venation, the most obvious being the veins ' $\mathrm{MP}+\mathrm{CuA}+\mathrm{CuPa} \alpha$ and $\mathrm{CuPa} \beta$ close, parallel and straight'. Very little is known about their body structures, young stages and biology. They could adapt to the important climatic changes and environments that happened between the Carboniferous and the middle Permian. They were widespread in the Laurussia but still unknown elsewhere during the Middle Permian.

For China, Hong and Wang (1976: 82-83, pl. 51, fig. 5-5a) described Sinogramma reticularis in the caloneurodean Pleisiogrammatidae Carpenter, 1943 from the Lower Cretaceous Guyang Formation (Inner Mongolia). It is in fact the cubito-anal area of a Dictyoptera Leach, 1818. Hong (1984: 147-148, fig. 22, pl. 63, fig. 3) described another early Cretaceous taxon (from Hebei) he attributed to the Caloneurodea, in the family Mesogrammatidae Hong, 1984, for the genus and species Mesogramma divaricata Hong, 1984, these names being later replaced by Hebeigrammidae, and Hebeigramma divaricata (Hong, 2003). This fossil has not the main synapomorphy of the Caloneurodea, viz. veins ' $\mathrm{MP}+\mathrm{CuA}+\mathrm{CuPa} \alpha$ and $\mathrm{CuPa} \beta$ close, parallel and straight'. After the original photograph of the holotype, the general shape of venation rather fits with a Phasmatodea Jacobson and Bianchi, 1902, but a revision of the type material would be necessary to precise its affinities.

Here we report the first discovery of a Chinese Caloneurodea from the middle Permian Yinping Formation near the Houdong Village, Chaohu City, Anhui Province, Southern China, 
corresponding at that time to a group of islands in the eastern margin of the paleo-Thetys, under a climate very different from those of the northern part of the Permian Pangea.

\section{Material and methods}

The fossil was preserved in the black shale of the Yinping Formation at the Paomaling Section near the Houdong Village, Chaohu City, Anhui Province, Southern China (detail map see Szwedo and Huang, 2019, fig. 2). Its age was assigned within the late part of Capitanian, Middle Permian (Zhang et al., 2018), or considered around the boundary of middle-late Permian (Yao et al., 2015). Our fossil was collected from the lower part of the formation that would be more convincing of the latest part of the middle Permian age.

The fossil wing was prepared using a sharp knife. Photographs were taken using a digital camera attached to a Zeiss Discovery V16 microscope. Line drawings were drafted with Adobe Illustrator CC 2018 graphic software.

We follow the wing venation terminology of Béthoux and Nel (2002) and the classification of the Caloneurodea of Béthoux et al. (2004). Abbreviations of wing venation: ScP subcostal posterior; RA radius anterior; RP radius posterior; MA media anterior; MP media posterior; $\mathrm{CuA}$ cubitus anterior; $\mathrm{CuP}$ cubitus posterior, $\mathrm{AA}$ anal anterior. urn:1sid:zoobank.org:pub:E83918BF-B83E-4381-84AF-2087540FBEE7

\section{Systematic paleontology}

Superorder Archaeorthoptera Béthoux and Nel, 2002

Subclade Panorthoptera Crampton, 1928 (sensu Béthoux and Nel 2002)

Order Caloneurodea Martynov, 1938

Family Aspidoneuridae Carpenter, 1961 
Type genus. Aspidoneura Carpenter, 1943. Other genera. Homaloptila Handlirsch, 1919, Sinaspidoneura gen. nov.

Genus Sinaspidoneura nov.

urn:1sid:zoobank.org:act:99DD11E0-CE59-4E1C-9E22-D1A323BDE239

Derivation of the name: Named after 'Sina', Latin name for China, and Aspidoneura. Gender feminine.

Type species: Sinaspidoneura magnifica nov. sp., here designed and by monotypy.

Diagnosis: Forewing ScP extending to wing apex; anterior branch of MA strongly sigmoidal; three branches of RP; base of RP very close to that of $\mathrm{M}+\mathrm{CuA}$, just distal to base of MA; vein AA2 absent or strongly reduced; wing basally petiolate with a reduced anal area.

Sinaspidoneura magnifica nov. gen., nov. sp.

Figs 1, 2, 3

rn:lsid:zoobank.org:act:DA69A668-67E2-4D5C-B604-3843FB61002C

Derivation of the name: Named after the wonderful state of preservation of the holotype.

Holotype: NIGP173204 (a complete wing, with part and counterpart, perfectly preserved); paratype NIGP173730, stored at the Nanjing Institute of Geology and Palaeontology, Chinese Academy of Sciences, Nanjing, China.

Type horizon and locality: Late Capitanian, middle Permian; Yinping Formation, Houdong Village, Chaohu City, Anhui Province, Southern China.

Diagnosis: As for the genus.

Description: (Based on holotype specimen) preserved part of wing $19.5 \mathrm{~mm}$ long, wing ca. $20.0 \mathrm{~mm}$ long, $4.1 \mathrm{~mm}$ wide; $\mathrm{ScP}$ reaching anterior wing margin at wing apex; RA and RP diverging ca. $3.8 \mathrm{~mm}$ distal of wing base; RA simple; first posterior branch from RP $8.6 \mathrm{~mm}$ 
distal of its origin; RP with two posterior branches, all simple; MA emerging from $\mathrm{M}+\mathrm{CuA}+\mathrm{CuPa} \alpha$ slightly basal of origin of RP; MA branched $4.9 \mathrm{~mm}$ distal of its origin; anterior branch of $\mathrm{MA}$ simple and strongly sigmoidal; $\mathrm{MP}+\mathrm{CuA}+\mathrm{CuPa} \alpha$ simple, strongly convex and straight; $\mathrm{CuPa} \beta$ and $\mathrm{CuPb}$ simple, straight, and concave; $\mathrm{AA} 1$ simple, straight, ending at level of base of $\mathrm{M}+\mathrm{CuA}$; AA2 not visible, possibly absent or very short at wing base; area between AA1 and posterior wing margin with one row of cells; crossveins all simple and straight; wing basally petiolated.

Paratype with same venation (Fig. 3).

\section{Discussion}

Sinaspidoneura nov. gen. falls in the Caloneurodea because of the following characters (Béthoux et al., 2004): in forewing, MA with only two branches; $\mathrm{MP}+\mathrm{CuA}+\mathrm{CuPa} \alpha$ simple; fusion of $\mathrm{CuPa} \alpha$ with $\mathrm{M}+\mathrm{CuA} ; \mathrm{MP}+\mathrm{CuA}+\mathrm{CuPa} \alpha$ (convex) and $\mathrm{CuPa} \beta$ (concave) close, parallel and straight (main synapomorphy); MP running fused with $\mathrm{CuA}+\mathrm{CuPa} \alpha$ at length. It has also the following additional characters, present in a majority of Caloneurodea: RP posteriorly pectinate when branched; anterior branch of MA strongly sigmoidal; marked convexity of crossveins; absence of anterior branches of RA.

Béthoux et al. (2004) gave a list of the species of the Caloneurodea, to which it is necessary to add the following taxa: Ligogramma wichita Beckemeyer, 2009 (early Permian, Okhlahoma, USA); Lusitaneura covensis Loureiro et al., 2010 (latest Carboniferous, Portugal); Isadistica issada Rasnitsyn et Aristov, 2013 (Isady, Vologda, Russia; Severodvinian); Aviogramma gracilis Prokop et al., 2014 (Avion, France Early Late Carboniferous); Gallogramma galadrieli Garrouste et al., 2018 and Paleuthygramma cf. acuta Carpenter, 1943 (Lodève, France, middle Permian). 
Sinaspidoneura nov. gen. differs from all the described Caloneurodea, except Aspidoneura flexa Carpenter, 1943 and Homaloptila similis (Meunier, 1911), in the conjunction of the following characters: 'ScP extending to wing apex' and 'anterior branch of MA strongly sigmoidal' (Zalessky, 1933; Carpenter, 1943, 1970; Béthoux et al., 2004). Some taxa, viz. Caloneurella carbonaria Carpenter, 1934 and Isadistica issada, have a long ScP nearly reaching wing apex, but they differ from Sinaspidoneura nov. gen. in the presence of four branches of RP or more, and the anterior branch of MA parallel to the posterior branch, with a narrower area between the two than in Sinaspidoneura nov. gen. (Carpenter, 1934; Rasnitsyn and Aristov, 2013). Pleisiogramma medialis Carpenter, 1943 has also a very long ScP, but a simple MA and four branches of RP. Synomaloptila longipennis Martynov, 1938 has a long $\mathrm{ScP}$, but four branches of RP and an anterior branch of MA strongly curved but not sigmoidal (Martynov, 1938).

Sinaspidoneura nov. gen. differs from Aspidoneura flexa in the less sigmoidal anterior branch of MA, the presence of three branches of RP, instead of two, and the base of RP very close to that of $\mathrm{M}+\mathrm{CuA}$, just distal to base of MA (Béthoux et al., 2004, fig. 15). Homaloptila similis has four branches of RP, but also a more pronounced sigmoid in the anterior branch of MA and the base of RP well distad of the base of MA (Béthoux et al., 2004, fig. 16). Aspidoneura and Homaloptila were classified together in the same family Aspidoneuridae with the following diagnosis: 'Sc extending to about the apex of the wing ; $\mathrm{CuA}$ and $\mathrm{CuP}$ very close together and nearly parallel; MP forked broadly and unevenly, the anterior branch (MP1+2) arching strongly away from MP3+4 ; 3 anal veins' (Carpenter, 1961, p. 151), that is, with the current terminology: $\mathrm{ScP}$ extending to wing apex; $\mathrm{MP}+\mathrm{CuA}+\mathrm{CuPa} \alpha$ and $\mathrm{CuPa} \beta$ very close together and nearly parallel (a character present in nearly all the Caloneurodea); anterior branch of MA strongly away from its posterior branch; three veins $\mathrm{CuPb}, \mathrm{AA} 1$ and AA2 present. 
Sinaspidoneura nov. gen. has all these characters except the presence of a vein AA2. More precisely, if AA2 is present, it should be a very short vein in the basally petiolate wing.

The strongly sigmoidal anterior branch of MA is a potential synapomorphy supporting the family Aspidoneuridae. The polarization of the character ' $\mathrm{ScP}$ extending to wing apex' is more uncertain. Thus we propose to place Sinaspidoneura nov. gen. in this family.

\section{Conclusion}

Homaloptila is known from the latest Carboniferous of Commentry in France, while Aspidoneura is known from the early Permian of Elmo (Wellington Formation, Oklahoma, USA). These two outcrops correspond to very different palaeoenvironments, viz. an equatorial hot and humid swamp-forest for Commentry while Elmo is supposed to have been 'a humid spot in a regional environment of more or less pronounced and long-continued aridity' (Carpenter, 1930, p. 72). Tasch (1964) interpreted the layers of Elmo with insects as limnic deposits; Zeller (1968: 50) indicated that the 'Wellington is predominantly shale with minor amounts of limestone and dolomite, siltstone, and gypsum and anhydrite', with 'marine and brackish- and fresh-water deposits'; Hall et al (2005) suggested a 'deposition in a marginalmarine environment'; and Beckemeyer (2000, p. 3) considered that the region was a 'coastal plain at the edge of an inland sea'. Thus the Aspidoneuridae could adapt to a more contrasted climate and environment between the Latest Carboniferous and the early Permian.

The Yinping Formation at Chaohu area, from where Sinaspidoneura nov. gen. comes, was a group of islands in the paleo-Thetys ocean, separated from the Pangea (and Laurussia) during the Middle Permian (Campi, 2012; Zhang et al., 2019, fig. 1). It was at the level of equator and probably under a much more humid and equally warm than the paleo-regions where the other Permian taxa of the Caloneurodea were found (Chumakov and Zharkov, 2002; Wang and Pfefferkorn, 2013). The very broad distribution of these insects during the Permian 
suggests that they could adapt to very different climates and biotas. Apparently the Caloneurodea are unrecorded in the late Permian. The younger ones are late Capitanian. Maybe they became extinct during the middle Permian crisis of diversity, maybe in relation to the 'major changeover in plant taxa' that happened at the end of the Guadalupian (Rampino and Shen, 2020).

\section{Acknowledgements}

We sincerely thank Pedro Correia and an anonymous referee for the useful comments on the first version of the paper. We are grateful to Jian Gao and Chenyang Cai for field work helps. This work was supported by the Strategic Priority Research Program of the Chinese Academy of Sciences (XDB18000000 and XDB26000000), and the National Natural Science Foundation of China (41925008 and 41688103).

\section{References}

Beckemeyer, R.J., 2000. The Permian insect fossils of Elmo, Kansas. The Kansas School Naturalist 46, 3-15.

Beckemeyer, R.J., 2009. Ligogramma wichita, a new species of Caloneurodea (Polyneoptera: Orthopterida) from the Lower Permian Wellington Formation of Noble County, Oklahoma. Journal of the Kansas Entomological Society 82, 300-304.

Béthoux, O., A. Nel., 2002. Venational pattern and revision of Orthoptera sensu n. and sister groups. Phylogeny of Palaeozoic and Mesozoic Orthoptera sensu n. Zootaxa 96, 1-88.

Béthoux, O., Nel, A., Lapeyrie, J., 2004. The extinct order Caloneurodea (Insecta: Pterygota: Panorthoptera): wing venation, systematics and phylogenetic relationships. Annales Zoologici 54, 287-300. 
Campi, M.J., 2012. The Permian - A time of major evolutions and revolutions in the history of life. pp. 705-718. In: Talent, J.A. (ed.). Earth and life. International Year of Planet Earth, Springer series.

Carpenter, F.M., 1934. Carboniferous insects from Pennsylvania in the Carnegie Museum and the Museum of Comparative Zoology. Annals of the Carnegie Museum 22, 323-342.

Carpenter, F.M., 1943. The Lower Permian insects of Kansas. Part 9. The orders Neuroptera, Raphidiodea, Caloneurodea and Prothortoptera (Prosbnisidae), with additional Protodonata and Megasecoptera. Proceedings of the American Academy of Arts and Sciences 75, 55-84.

Carpenter, F.M., 1961. Studies on Carboniferous insects of Commentry, France. Part 3. The Caloneurodea. Psyche 68, 145-153.

Carpenter, F.M. 1970. Fossil insects from New Mexico. Psyche, 77: 400-412.

Chumakov, N.M., Zharkov, M.A., 2002. Climate during Permian-Triassic Biosphere Reorganizations. Article 1: Climate of the Early Permian. Stratigraphy and Geological Correlation 10, 586-602. [Translated from 2002. Stratigrafiya, Geologicheskaya Korrelyatsiya 10, 62-81.]

Crampton, G.C., 1928. The grouping of the insect orders and their lines of descent. The Entomologist 61, 82-85.

Garrouste, R., Lapeyrie, J., Steyer, J.-S., Giner, S., Nel, A., 2018. Insects in the Red Middle Permian of Southern France: first Protanisoptera (Odonatoptera) and new Caloneurodea (Panorthoptera), with biostratigraphical implications. Historical Biology 30, 546-553.

Hall, J.D., Mazzullo, S.J., Beckemeyer, R.J., May, W.J., 2005. Depositional facies and diagenesis of the Carlton Member (sic) (Kansas) and the Midco Member (Oklahoma) of the Wellington Formation (Sumner Group, Leonardian) (abs.). Transactions of the Kansas Academy of Science 108, 168. 
Handlirsch, A., 1919. Revision der paläozoischen Insekten. Denkschriften der Kaiserlichen Akademie der Wissenschaften, Mathematisch-Naturwissenschaftliche Klasse 96, 511-592. Handlirsch, A., 1937. Neue Untersuchungen über die fossilen Insekten mit Ergänzungen und Nachträgen sowie Ausblicken auf phylogenetische, palaeogeographische und allgemein biologische Probleme. I Teil. Annalen des Naturhistorischen Museums in Wien 48, 1-140. Hong, Y.-C., 1984. [Tracheata, Insecta.] pp. 128-185. In: [Paleontological atlas of North China. 2. Mesozoic volume.] (ed. Tianjing Institute of Geology and Mineral Resources). Geological Publishing House, Beijing, 384 pp. [in Chinese].

Hong, Y.-C., 2003. Hebeigramma nom. nov., a new name for Mesogramma Hong, 1984 (Caloneurodea) from the Lower Cretaceous of Hebei Province, China. Geological Bulletin of China 22, 687-688.

Hong, Y.-C., Wang, W.-L., 1976. Insecta. In: Palaeontological atlas of North China. Inner Mongolia, 2. Mesozoic and Cenozoic. Science Press, Beijing, 81-87. [in Chinese.]

Jacobson, G., Bianchi, V., 1902-1905. Priamokrylyia i lozhnostchatokrylyia Rossiiskoi imperii. Dewrien, A.F. (publ.), St. Petersburg, 1-846. [In Russian]

Leach, W.E., 1818. The zoological miscellany; being descriptions of new interesting animals. Volume 3, London, 377-399.

Loureiro, J.P., Correia, P., Nel, A., Pinto de Jesus, A., 2010. Lusitaneura covensis n. gen., n. sp., first Caloneurodea from the Carboniferous of Portugal (Insecta: Pterygota: Panorthoptera). Annales de la Société Entomologique de France (N.S.) 46, 242-246. Martynov, A.V., 1938. [Permian fossil insects from the Arkhangelsk district. Part 5. The family Euthygrammidae and its relationships, with the description of a new genus and family from Chekarda.] Trudy Paleontologicheskogo Instituta Akademii nauk SSSR 7, 69-80. [in Russian, with a summary in English.] 
Meunier, F., 1911. Nouveaux insectes du houiller de Commentry. Bulletin du Muséum National d'Histoire Naturelle de Paris 17, 117-127.

Olivier, G.A., 1789. Encyclopédie méthodique. Histoire naturelle, Tome quatrième, Insectes. Panckoucke, libraire, Paris, 1-331.

Prokop, J., Roques, P., Nel, A., 2014. New non-holometabolous insects from Pennsylvanian of Avion locality in Pas-de-Calais, France (Insecta: 'Exopterygota'). Alcheringa 38, 155-169.

Rampino, M.R., Shen, S.-Z., 2020. The end-Guadalupian (259.8 Ma) biodiversity crisis: the sixth major mass extinction? Historical Biology, https://doiorg.proxy.mnhn.fr/10.1080/08912963.2019.1658096

Rasnitsyn, A.P., Aristov, D.S., 2013. 2.1. New Fossil Insects (Insecta: Caloneurida, Hypoperlida, Palaeomanteida, Jurinida) from the Middle and Upper Permian of European Russia. Pp. 678-704. In: Aristov, D.S., Bashkuev, A.S., Golubev, V.K., Gorochov, A.V., Karasev, E.V., Kopylov, D.S., Ponomarenko, A.G., Rasnitsyn, A.P., Rasnitsyn D.A., Sinitshenkova, N.D., Sukatsheva, I.D. and Vassilenko, D.V. (eds). Fossil insects of the Middle and Upper Permian of European Russia. Paleontological Journal 47, 641-832.

Sharov, A.G., 1968. Filogeniya ortopteroidnykh nasekomykh. Trudy Paleontologicheskogo Instituta, Akademiya Nauk S.S.S.R. 118, 1-216, Moskva. [in Russian, Translated in English in 1971: Phylogeny of the Orthopteroidea. Israel program for scientific translations, Keter Press, Jerusalem, 1-251.]

Szwedo, J., Huang, D.-Y., 2019. First Dysmorphoptilidae from the Permian of China (Hemiptera: Cicadomorpha: Prosbolomorpha), with notes on the fossil record of the family. Palaeoentomology 2, 148-170.

Wang, J., Pfefferkorn, H.W., 2013. The Carboniferous - Permian transition on the North China microcontinent - Oceanic climate in the tropics. International Journal of Coal Geology 119, $106-113$ 
Yao, X., Zhou, Y.Q., Hinnov, L.A., 2015. Astronomical forcing of a Middle Permian chert sequence in Chaohu, South China. Earth and Planetary Science Letters 422, 206-221.

Zalessky, G.M., 1933. Sur de nouveaux insectes permiens. Annales de la Société Géologique du Nord 57, 135-144.

Zhang, B.-L., Yao, S.-P., Hu, W.-X., Hai, D., Liu, B., Ren, Y.-L., 2019. Development of a high-productivity and anoxic-euxinic condition during the late Guadalupian in the Lower Yangtze region: implications for the mid-Capitanian extinction event. Palaeogeography, Palaeoclimatology, Palaeoecology 531, 1-16.

Zeller, D.E. (ed.), 1968. The stratigraphic succession in Kansas. Kansas Geological Survey, Bulletin 189, 1-81.

Fig. 1. Sinaspidoneura magnifica gen. et sp. nov., holotype NIGP173204, photographs of forewing. A. Part (NIGP173204a). B. Enlargement of A showing details of wing base. C. Enlargement of A showing details of wing apex. D. Counterpart (NIGP173204b). Scale bars: 2 $\mathrm{mm}(\mathrm{A}, \mathrm{D}), 1 \mathrm{~mm}(\mathrm{~B}, \mathrm{C})$.

Fig. 2. Sinaspidoneura magnifica gen. et sp. nov., line drawing, small black arrow: base of MA. Scale bar: $2 \mathrm{~mm}$.

Fig. 3. Sinaspidoneura magnifica gen. et sp. nov., paratype NIGP173730, photographs of forewing. A. Part. B. Counterpart. Scale bars: $1 \mathrm{~mm}$. 


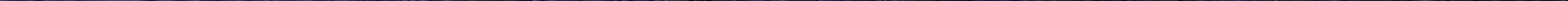




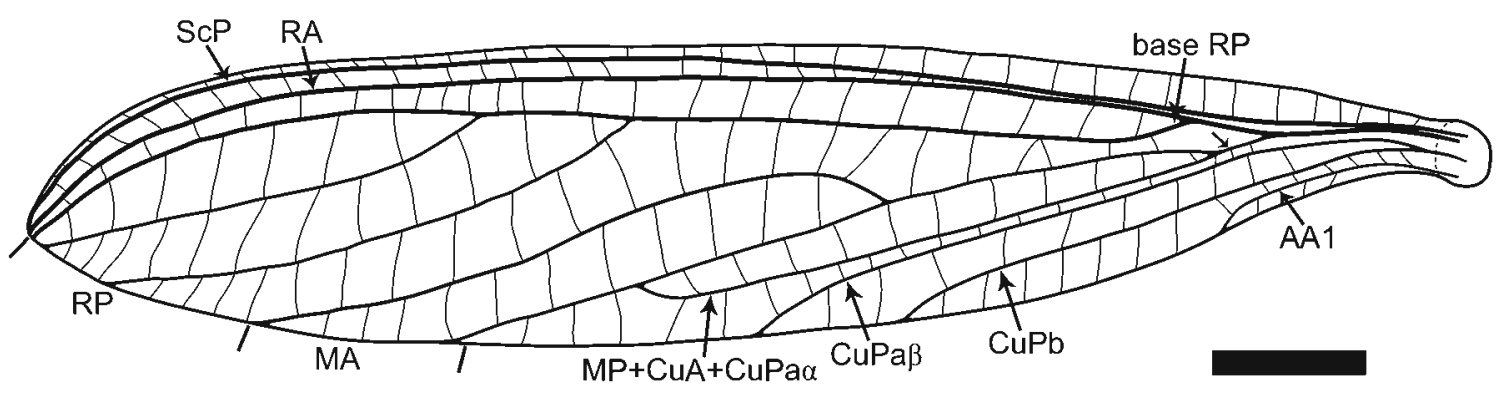


$\mathbf{A}$

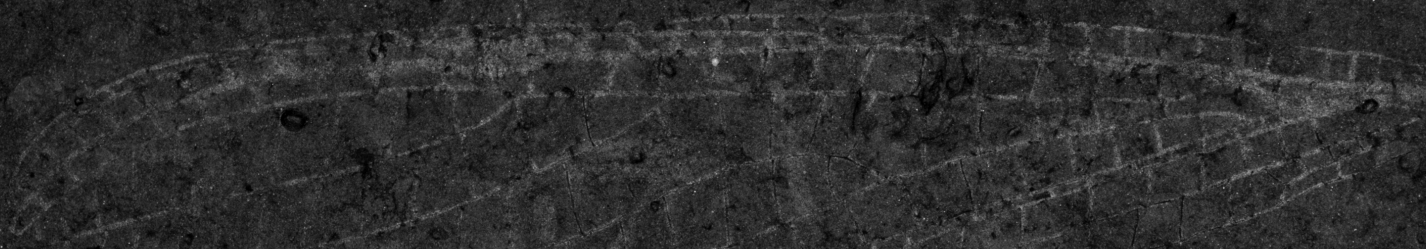

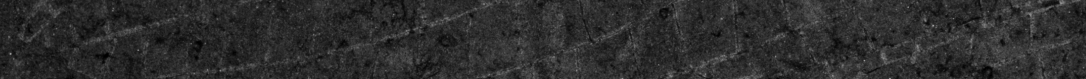

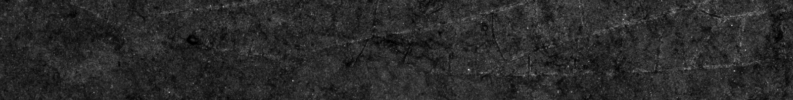

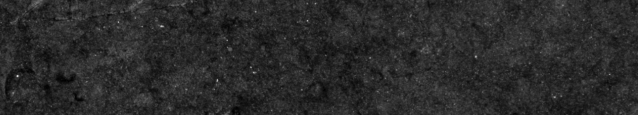

B

Si. $\rightarrow$.

8

2. $2,5+2 x^{2}+8$

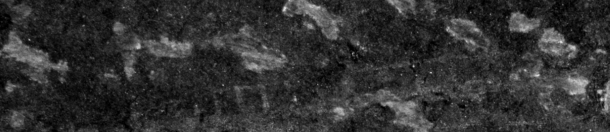

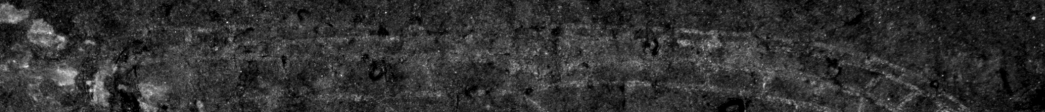

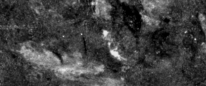

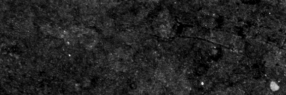

Y.7. $x^{2}+2+2$

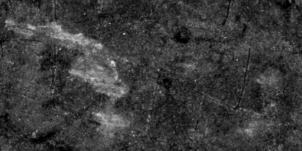

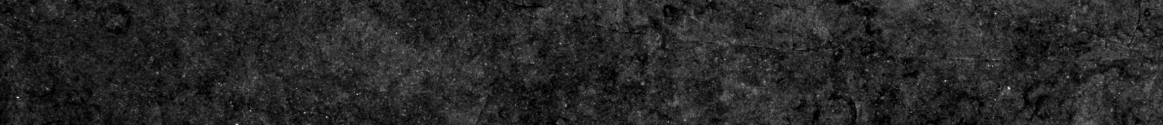

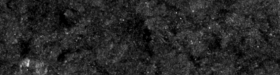

